\title{
The Office of the
}

\section{un High Commissioner for Refugees: Continuing Challenges after a Half Century}

\author{
Gerald Dirks
}

\section{Abstract}

The world's refugee phenomenon attracted oscillating levels of interest from governments as early as the inter-war era. Only with the establishment of UNHCR a half-century ago, however, did governments reluctantly acknowledge that managing the refugee phenomenon required an institutional structure and a genuine, continuous, multilateral effort by the international community.

Since the founding of $\mathrm{UNHCR}_{\mathrm{H}}$, its role, operational approach, and, according to some observers, even its mandate have changed remarkably. Governments, frequently wavering in their support for these modifications, have at least begrudgingly endorsed UNHCR's efforts in order to limit the spread of political instability, which too often resulted in regional economic turmoil and widespread despair.

This paper analyzes how effectively and at what political and fiscal cost UNHCR has dealt with intensifying refugee flows in light of shifting priorities of governments, themselves the policy and budgetary masters of this un body. To achieve this, the reasons behind UNHCR's expanded responsibilities are identified, the agency's important advocacy work is analyzed, and its expanded role and constantly altering operational approach are examined. Despite the innumerable obstacles that have confronted the agency over the past half century, the conclusions suggest that at least partial success has been achieved.

\section{Résumé}

Dès les années d'inter guerres, le phénomène des réfugiés dans le monde a commencé à susciter l'intérêt oscillant des gouvernements nationaux. Cependant, ce n'est qu'avec la mise sur pied du HCR - il y a de cela un demi-siècle - que les gouvernements ont été amenés à reconnaître, un peu malgré eux, que la tâche de s'occuper du phénomène des réfugiés nécessitait une structure institutionnelle ainsi qu'un effort multilatéral, continue et sérieux, de la part de la communauté internationale.

Depuis sa fondation, le rôle $d u \mathrm{HCR}$, son approche opérationnelle et, selon certains observateurs, son mandat même, ont changé de manière très nette. Les gouvernements qui sont souvent hésitants dans leur soutien à de telles modifications, ont tout de même fini par soutenir les efforts du HCR afin d'éviter que ne se répande l'instabilité politique et que ne se produisent les bouleversements économiques de régions tout entières et le désespoir humain à grande échelle qui en sont trop souvent le résultat.

Cet article examine le degré de succès qu'à eu le HCR à s'occuper des flots grandissants de réfugiés et le prix politique et fiscal qu'il a fallu payer pour y arriver, spécialement à la lumière des priorités changeantes des gouvernements qui, précisément, sont les maîtres contrôlant les affaires budgétaires et les politiques de cet organisme des Nations Unies. Pour atteindre ses objectifs, l'article identifie les raisons expliquant les responsabilités accrues $d u$ HCR, analyse son travail important d'intervention et examine son approche opérationnelle qui change constamment. 
Malgré les innombrables obstacles qui ont confronté l'agence au cours des cinquante dernières années, les conclusions suggèrent qu'un succès partiel a tout de même était atteint.

$\mathrm{T}$ he constant change and dynamic character of international political phenomena are widely accepted among students and practitioners working in all aspects of international relations. A second view, just as widely held, is that, despite the chronic tension that promoted hostility and distrust, the forty years of the cold war provided a semblance of order and relative stability within the international system. Yet, even during those years of bipolar dominance when a kind of predictability prevailed, and certainly throughout the final decade of the century, the issues demanding and receiving attention from governments and intergovernmental organizations did not remain static but rose and fell on agendas in accordance with continually altering perceptions of urgency. At the same time, what were seen as potential or actual threats to state security increased, moving from the traditional primary concern for physical danger posed by military actions, to a growing sense of unease over a host of matters, formerly thought of as "low politics," such as competition over trade, anxiety over environmental problems, and, most significantly for this paper, massive involuntary cross-boundary population movements.

As early as the period preceding the outbreak of World War II in Europe, but even more so during the past fifty years, governments collectively show varying levels of interest in what is now routinely referred to as the refugee phenomenon. The motives behind this escalating degree of concern are complex but include the desire to limit and restrict political instability, which regularly contributes to economic turmoil and profound humanitarian despair.

In the aftermath of World War II, the international community established machinery to repatriate or integrate hundreds of thousands of persons-primarily Europeans, displaced as a result of the war-into new would-be homelands, Subsequently, governments had to reluctantly acknowledge that the "refugee problem" was not going to be eliminated but rather showed indications of intensifying. International efforts then turned to managing and, where possible, limiting the extent of this unwanted involuntary migration. After substantial debate on the creation of more than just a temporary agency to deal specifically with the international refugee situation, on December 14, 1950, the United Nations General Assembly (GA) adopted Resolution 428 and established the Office of the United Nations High Commissioner for Refugees (UNHCR), which formally began operations in 1951. ${ }^{1}$ This significant multilateral organization is now a half-century old and continues to confront a host of seemingly intractable humanitarian and political issues, many having their origins in the era in which the agency was still in its infancy.

At the outset, UNHCR's mandate was quite limited. Put succinctly, the agency's purpose was to encourage governments to provide fair and just treatment to genuine refugees. To do this, governments were encouraged to accede to the newly drafted Convention relating to the Status of Refugees. When states adhered to it, it would provide a degree of legal protection, including a series of rights such as asylum but also additional entitlements that enabled refugees to seek employment and education, and to qualify for social welfare. ${ }^{2}$ UNHCR, therefore, would work not only to have governments ratify the Convention, but would also monitor state behaviour to ensure adherence to the provisions of that document. The GA resolution creating the Office also charged it with the daunting task of seeking permanent solutions to the world's refugee problem. The approaches subsequently adopted have focused upon three options: voluntary repatriation, integration into the states where refugees had been granted asylum, and permanent resettlement in willing third countries.

During its first decade, UNHCR attained the characteristics of a permanent structure. First, the High Commissioner convinced the GA that UNHCR should be permitted to solicit voluntary financial contributions to assist refugees when no other means of support were available. Second, an advisory committee of interested governments was established to counsel the High Commissioner on how to manage and utilize these still small voluntary contributions from governments. Third, the advisory committee gradually evolved into an executive committee with an expanded membership, which accepted additional tasks associated with the overall direction of UNHCR. By the end of UNHCR's initial ten years of existence, its concerns had become global, as Europe's refugee situation was surpassed in size and scope by emergencies in Africa, Asia, and ultimately Latin America. ${ }^{3}$

The objective of this paper is to trace the evolution and development of UNHCR during its half-century of operation. The goals are to discuss and analyze how effectively and at what cost UNHCR has dealt with the increasing flow of involuntary migrants in the light of the shifting government priorities of over the past fifty years that have hindered the emergence and maintenance of consensus within the international community. To achieve this, I first identify and examine UNHCR's expanded set of responsibilities 
during its lifetime, both in number and scope, and analyze how that state of affairs has arisen. Next, I focus on UNHCR's advocacy efforts which, while part of the agency's original mandate, have expanded significantly. Finally, drawing upon these first two segments, the paper provides linkage between the expanded role of UNHCR and the ongoing alterations in its structure and its administrative and operational approach. As part of this analysis, the efforts UNHCR has made to become a more transparent and accountable entity will receive attention. This paper now turns to the issue of UNHCR's enlarged or "creeping" mandate.

\section{UNHCR's Expanding Responsibilities}

Since UNHCR's inception fifty years ago, its activities have expanded significantly, the result of a combination of two factors. First, the organization's goals and purposes have become more encompassing. Second, the expanded goals have required the adoption of additional strategies to achieve those ends. The resolution that created UNHCR clearly limits its tasks to providing legal protection to genuine refugees and to striving towards the eradication of the refugee phenomenon. Over time, however, the approaches adopted by the Office to achieve these objectives have become more numerous and complex. It may be that the agency's ends and the means adopted to attain those ends have expanded. The challenge is to try to explain why agency operations have grown and administrative processes have altered to the extent that they have.

Specifically, in what areas have UNHCR's mandate and administrative operations expanded over the past halfcentury? As pointed out above, when UNHCR was formed, it was expected to adopt a narrow and clearly delineated range of activities. One student of UNHCR's early years has written that "East-West tensions together with Western disagreements over priorities ensured that the mandate of UNHCR was subject to a highly partisan interpretation while its operational framework reflected compromise and cautious liberality." ${ }^{4}$ The Office was authorized to work towards eliminating the refugee phenomenon, an objective unlikely ever to be attained. The real focus, however, was on providing international legal protection to persons fitting the Convention's definition of a refugee. The agency accordingly sought to have governments accede to this Convention relating to the Status of Refugees and then attempted to ensure that its provisions were adopted and adhered to by those countries.

Very early in UNHCR's existence, the High Commissioner, his small staff, and even a few interested governments recognized that this limited mandate, if rigidly followed, was too restrictive to meet the mounting needs of bona fide refugees. When in excess of 200,000 Hungarians fled their homeland in late 1956, following an unsuccessful uprising against the occupying forces of the Soviet Union, the United Nation's GA enlarged UNHCR's mandate by authorizing it to raise funds to assist these refugees and to generally coordinate care and maintenance efforts. By 1960, having gained permission to solicit voluntary financial contributions, another GA resolution permitted UNHCR to contract out programs to non-governmental organizations and subsequently to government agencies to provide material assistance to refugees beyond Europe, where states of asylum were unable or unwilling to meet basic refugee needs. Throughout the next three decades, UNHCR's operations expanded constantly as the number of Convention refugees rose substantially, especially in Asia, Africa, and Latin America, where developing countries could not provide life's necessities. ${ }^{5}$ This enormous rise in forced migration was caused in large part by the increase in generalized violence. Specifically, external aggression, intensifying internal conflicts such as civil wars and massive violation of human rights—all compelling populations to flee-could not be entirely ignored by the international community. As refugee numbers mounted, UNHCR's strenuous fundraising initially resulted in millions then tens of millions of dollars being made available by government contributions to cover costs of contracting other agencies within and outside the UN system to dispense care and maintenance assistance. ${ }^{6}$ In recent years, contrary to the intent of its founders, the Office itself has become an operating agency in the field, augmenting the work of the contracting organizations.

The most significant extension of the Office's mandate came during the nineties when, through still another GA resolution, it was authorized to provide protection as well as care and maintenance to persons who were not refugees in the rigid sense of the term as defined by the Convention, but who were in refugee-like situations. An indication that such an expansion in eligibility criteria was being considered came with a report prepared for the 1992 session of the Executive Committee. The background paper stated that the mounting humanitarian emergencies "underlined to some extent the need for supplementing traditional protection notions and approaches with protection activities in new areas."' The report urged UNHCR to forge responses to the massive population displacement that would be innovative and practical, balancing humanitarian concerns with political realism, and states' interests with the rights and needs of refugees and persons in refugeelike circumstances. ${ }^{8}$ 
One category of persons formerly outside the mandate, but now standing to receive assistance from this broadened outlook, was internally displaced people. To elaborate, one of the criteria for being classed as a refugee according to the 1951 Convention is that such persons had to be outside their state of origin or habitual residence. This alteration in UNHCR's mandate has permitted the agency to assist "internally displaced persons." Thus, people encountering persecution and threats to their lives may receive UNHCR protection even though they have not, possibly for reasons beyond their control, fled their homelands. This condition prevailed during the nineties in a number of countries including Somalia, several states in the Great Lakes region of East Africa, and in the former Yugoslavia. Reporting to the 1992 session of the Executive Committee, UNHCR explained the extension in its operations as follows: “UNHCR's role over the past forty years has demonstrated that the mandate is resilient enough to allow or require adaptation by UNHCR to new, unprecedented challenges through new approaches." The report went on to assert that UNHCR would continue to seek specific endorsement from the UN secretary-general or the GA where "these activities involve a significant commitment of human, financial and material resources. ${ }^{\prime \prime 0}$ The following year, as if to legitimize still further the expanding mandate, UNHCR wrote, "The GA and Executive Committee have expressed their support for UNHCR's efforts to explore new options and undertake new protection activities . . . consistent with the mandate." Referring directly to the plight of internally displaced persons, the document stated that they would be assisted "where it has been practically and morally untenable to make distinctions as to who should receive humanitarian assistance or protection on the basis of legal mandates derived from prior status rather than current need."12 This same document declared that the state in which persons have been internally displaced must concur in UNHCR's activities but, on a number of occasions where legitimate authority has not been present, the agency has still initiated activities, often with the support of other UN specialized agencies.

The final example of UNHCR's expanding mandate to be cited here, although others of similar importance could certainly be added, concerns monitoring the welfare of refugees who have been repatriated, possibly prematurely. More frequently now than in the past, UNHCR personnel, encouraged by some Executive Committee member governments, are endeavouring to limit expenses where possible by urging refugees to return to their homelands. While all organizations and governments associated with the refugee phe- nomenon are eager to see an end to protracted population displacement, conditions in the states of origin are often still politically fragile, and conflict may not have entirely concluded. No doubt the tragic slaughter in Rwanda in 1994 and the subsequent general turmoil and anarchy in the Great Lakes region of East Africa accounts, to some degree, for the intensifying anxiety about the fate of newly repatriated refugees. In a document prepared for the Executive Committee in 1995, UNHCR did assert that it has had "a legitimate concern for the welfare of returnees ... and it is given effect through monitoring their safe and effective re-integration into their country of origin." ${ }^{13} \mathrm{Gov}-$ ernments' increased use of temporary rather than permanent asylum for refugees and the withdrawal of this protection, forcing repatriation when it may have been inappropriate, or at least premature, may also have caused UNHCR to try to monitor situations in the homeland-a task it had not formerly attempted. Yet, unlike the decision to provide assistance to internally displaced persons for which numerous authorizations can be found, evidence for the formal authorization of UNHCR to undertake systematic monitoring of returnees is scarce. According to one source, the monitoring has, in fact, been very selective and sporadic, at best. ${ }^{14}$ Representatives of UNHCR and nongovernmental organizations (NGOS) with field staff operating in many conflict-filled regions agree that there may be a need to observe conditions in some states to which refugees have been repatriated. ${ }^{15}$

Throughout the past decade, there has been a qualitative change in the political environment in which UNHCR operates. "The agency appears to be under increasing pressure to promote repatriation as a durable solution to the problems of mass population movement." ${ }^{16}$ In addition, the states providing the sanctuary had expected this assistance to be only temporary, but to local authorities scrambling for adequate resources for the indigenous population, let alone any foreign refugees, it feels interminable. The extent of frustration when combined with undeniable humanitarian concern can be sensed in the following quotation from an UNHCR document:

Many refugees have not been able to repatriate voluntarily. Neither have they been able to integrate locally. Nor have they been resettled elsewhere. Formidable crises and emergencies have hardened into impenetrable and seemingly deadlocked dilemmas, resisting or failing to attract determined and concerted international solutions. ${ }^{17}$

As recently as the forty-ninth session of UNHCR's Executive Committee, in October 1998, reference continued 
to be made to the potential and/or actual danger confronting returnees, especially women and children, who constitute almost three-quarters of most refugee movements. Similarly, at this same session, government delegates and UNHCR staff alike expressed their ongoing concern for persons internally displaced but not yet receiving any protection or assistance from any organization, governmental or non-governmental. ${ }^{18}$

These examples of a broadening and deepening UNHCR mandate are not exhaustive but illustrative only. Yet, they do provide the reader with a sample of the growing operations and indicate why alterations in administrative structures and managerial approaches have been necessary, a subject turned to in a later segment of this paper.

\section{Linking Refugee Protection with Intensifying Advocacy}

Each year, before UNHCR's Executive Committee meets, officials and member government representatives select a theme for discussion. In 1999, "strengthening partnership to ensure protection" was the focus. Truly, protection lies at the heart of UNHCR's mandate. "Protection encompasses all activities aimed at restoring the human dignity of refugees, safeguarding their rights, and seeking durable solutions to their problems." ${ }^{19}$ From its earliest years, in an effort to protect persons falling within its mandate, the agency has advocated on their behalf. That advocacy has taken a variety of forms and, throughout the past five decades, has expanded significantly. The scope and priority given to encouraging protection by governments has become enormously important, indeed. The longest standing of the advocacy objectives pursued by the agency has centred on persuading governments to accede to the two primary international refugee protection instruments: the 1951 Convention relating to the Status of Refugees, and its 1967 Protocol. Acquiring those accessions has not been a simple task. Even as the agency passes its fiftieth birthday, the goal that UNHCR and non-governmental organizations concerned about the welfare of refugees would like to have reacheduniversal adherence to the international instruments-has eluded them. Not surprisingly, liberal democratic governments-frequently but not always far from refugeeproducing circumstances, and in a better position to effectively regulate the entry of aliens-were the first to adhere to the instruments. In marked contrast, states in refugeeproducing neighbourhoods and with unresponsive, unaccountable governments have often rejected UNHCR's efforts to have them become signatories. As recently as this past decade, UNHCR efforts to acquire accessions continued to focus on governments in the Middle East, Asia, and Oceana. ${ }^{20}$ The disappointments notwithstanding, 138 governments were parties to both instruments, as UNHCR reached its half- century mark.

Even when governments have signed on to the international instruments, this does not, in many instances, end UNHCR's advocacy work with those authorities. Too frequently, according to the agency, governments fail to abide by some of the major provisions of the Convention or its Protocol. Since the origins of UNHCR, it has acknowledged that a major portion of its protection work has been to ensure that the provisions of the Convention are incorporated into legislation in states that have adhered to this international instrument. In a document prepared for the 1990 session of the Executive Committee, UNHCR asserted that the Convention "reflected the determination of the international community to protect and assist vulnerable groups of persons within the framework of international law and on the basis of international solidarity." ${ }^{21}$ The document went on to explain that, despite these arrangements and understandings, "the refugee problem today is bigger and more complex than ever." 22 Thus, advocacy has had to be intensified as the available resources and the political will are no longer adequate to meet refugee needs. Governments have come to see mass population shifts as unwanted immigration rather than genuine refugee movements. In a report prepared for the 1999 meeting of UNHCR's Executive Committee, the view was expressed that the agency was "not only confronted with a refugee situation of broadening scope and deepening complexity, but also with an increasing reluctance of states to grant the necessary protection within the agreed international framework." ${ }^{23}$

UNHCR's constant awareness of its mandate to pursue solutions to the global refugee problem has caused it to intensify its advocacy programs in an effort to convince governments to adopt programs and policies that support overall assistance to refugees, as well as to persons in refugeelike situations. In its attempt to raise awareness and alter restrictive attitudes of governments and publics towards refugees, UNHCR has constantly emphasized that its objectives and programs are purely humanitarian, having no political goals whatsoever.

From time to time, UNHCR has indicated that it would favour additional international global instruments to supplement the Convention and its Protocol. Such instruments would address the limitations of the 1951 Convention and should ideally be treaties or conventions rather than mere declarations or resolutions, which are not enforceable. ${ }^{24}$ 
At the moment, no global instruments focus on the plight of persons fleeing general violence and/or armed conflict. ${ }^{25}$ It appears, however, that governments have little inclination to draft and adopt any new protection measures that specifically focus upon refugees. ${ }^{26}$ In the absence of new universal instruments, UNHCR encourages governments to also adhere to such regional international protection instruments as that of the Organization of African Unity and the less effective Cartagena Declaration of the Organization of American States. ${ }^{27}$ The regional instruments are intended to take into consideration historic and cultural traditions in specific parts of the world. For example, the Cartagena Declaration refers to forms of diplomatic asylum that Latin American governments have agreed upon for more than a half century.

Acquiring accessions by governments to the 1951 Convention and then striving for adherence to the principles contained in these instruments are only two of many advocacy tasks with which UNHCR is involved. Examples of the sort of policies and practices relating to refugee welfare that UNHCR strives to modify include unwarranted detention of refugee claimants in closed holding centres or prisons, refusal by governments to grant even temporary asylum to persons in flight, returning refugees to their states of origin when their lives would be endangered, and preventing persons from seeking gainful employment or their children from attending school. It also endeavours to prevent physical and sexual abuse and intimidation, particularly of women and girls. Discouraging the use of refugee children as soldiers has also become a part of UNHCR's advocacy approach. Addressing these and other equally serious concerns has been frustrating, time-consuming, and frequently unsuccessful. UNHCR's advocacy pursuits are sometimes complicated by a desire to press these matters with governments without alienating or annoying them to the extent that their annual financial contributions, needed so much, will be decreased or even cancelled..$^{28}$

Arbitrary detention and refoulement - the act of forcibly returning refugees to their homelands-are especially worrying to agency officials and head the list of ills upon which advocacy is focused. When seeking to liberalize detention policies that governments have implemented, UNHCR has asserted that physical confinement should be used only in exceptional instances and not as the norm. According to the agency, governments should avoid closed, prison-like camps surrounded by barbed wire and patrolled by armed troops and guard dogs. ${ }^{29}$ Imprisonment and/or refoulement have become increasingly prevalent as more and more governments interpret the mass shifts in population as little more than attempted immigration through the back door. While UNHCR acknowledges that, given the principles of classical sovereignty, states have the undeniable right to control their borders and determine eligibility for entry, governments are inclined to be inflexible and illiberal, erecting obstacles in the paths of persons seeking sanctuary. As the century concluded, UNHCR felt compelled to step up its advocacy initiatives as, in its view, states demonstrated an increasingly "narrow interpretation of their international obligations and humanitarian responsibilities." 30

Another dimension of UNHCR's advocacy work revolves around encouraging governments to establish fair and equitable processes for determining refugee status. UNHCR representatives have, therefore, endeavoured to see that governments put more humane status-determination procedures into binding legislation and have offered their services to instruct government officials unfamiliar with the issues that relate to determining valid refugee claims. In many countries, including Canada for several years, the agency's representative, a quasi-diplomatic official, is part of the determination process, who has access to the refugee claimant files and, on occasion, even sits with the statusdetermination panels.

During recent years, the High Commissioner, with UNHCR officials, has urged governments to work with UNHCR to establish mechanisms that provide early warning of potential mass refugee emergencies. Undoubtedly, the tragic events during 1994 in Rwanda and subsequently throughout the Great Lakes region of East Africa with their enormous costs in human lives account, at least partially, for this undertaking.

Many additional examples of advocacy on behalf of refugees could be discussed. Suffice it here to emphasize that, in virtually every statement by the High Commissioner and in almost all documents relating to international refugee protection, a fervent plea is made to the community of states to do more to alleviate the intolerable conditions facing millions of persecuted, dislocated people. Burden-sharing is a frequent theme in these appeals. Although the speeches and agency publications adhere to the conventional sanitized form of the Un system, the profound feeling for the plight of refugees is still detectable. All this advocacy has taxed the capacity of UNHCR and has contributed to modifications in the operation of the organization and a still greater need to attract financial contributions for all programs, as UNHCR enters its second half-century. 


\section{Pressures for Budgetary and Managerial Modifications}

Administrative, managerial, and other operational modifications have been made at UNHCR as a result of the conditions and circumstances discussed previously. Even if fewer demands had been made on UNHCR during the past half-century, some alterations in its operations would still have likely occurred. To illustrate, the changing international political environment, when combined with increasingly shrill, intransigent attitudes and policy preferences of many governments, has actually intensified the need for UNHCR to adapt. The politicization of policy and decisionmaking approaches, particularly the budgetary process, at the Geneva headquarters has undoubtedly contributed to the difficulties high commissioners have faced in trying to implement programs.

Muddling through and ad hoc measures have characterized a large proportion of UNHCR's operations for much of the agency's existence. Refugee emergencies, budgetary shortfalls, and ambiguous signals from member governments and senior UN personnel provided an explanation and justification for many informal administrative practices affecting policy and program implementation. Whatever operational approaches or administrative plans were utilized, UNHCR officials defended them as necessary for fulfilling the ever-expanding mandate and humanitarian requirements of the situation.

While many factors have had an impact on the structure and operations of UNHCR, budgetary considerations, controversial at the best of times, certainly head the list. For all intents and purposes, UNHCR's funds come from voluntary contributions by governments. The annual budget for most of the agency's existence has allocated these monies into general programs (those dealing with ongoing refugee care and maintenance), or special programs (the unexpected emergencies that appear to be always with UNHCR). Steps are now being taken to unify this budget process. The agency's annual budget during the nineties became large by any measure and appears to be maintaining that level in this new century. Between 1990 and 1992, the annual budget took an enormous leap, almost doubling from us $\$ 544$ million to us $\$ 1.07$ billion. This absolutely unexpected growth resulted from a succession of huge population displacements caused by wars and near wars in Iraq, Somalia, the Caucasus, Croatia, and Bosnia. Following the colossal human disaster in Rwanda, UNHCR's budget in 1995 reached an amazing us $\$ 1.3$ billion..$^{31}$ In the business world, this rapid growth would be reason for celebration. In the world of humanitarian agencies, it was a reflection of the chaos and anarchy that has tragically occurred since the end of the cold war.

Such an increase in the annual budget had UNHCR entering a totally new league. Not surprisingly, as the budget has grown, monitoring by the approximately fifty governments, now members of the agency's Executive Committee, has substantially increased. These governments have demanded a greater degree of accountability and transparency from all departments within UNHCR. Uncertainty about meeting the annual financial goal has mounted as the sums requested by UNHCR have become larger. The unstable, unpredictable funding introduced a previously unknown level of anxiety among the major donor states and was a significant factor contributing to the resignation of two high commissioners within eighteen months in the early 1990 s.

The fiscal crises with the inevitably escalating calls for controls by member governments resulted in a special working group being struck in 1991 composed of a few of the major donor states from the Executive Committee. One major recommendation brought forward by this group, and accepted by the Executive Committee, required UNHCR's budget to be developed on the basis of available voluntary funds rather than on projected refugee needs. ${ }^{32}$ While this recommendation brought a greater degree of fiscal responsibility to the budgetary process, it has not by any means put an end to the ongoing search for funds, or efforts to streamline the agency's administrative operations at headquarters in Geneva or in the field where programs for refugees are delivered. UNHCR has had to try to balance humanitarian concerns with the cold and harsh truths arising from political and fiscal reality.

Despite an intentional decrease in staff positions at headquarters and in the field, as well as other efforts adopted to limit expenditures, financial issues had become especially acute by early 1998. The director of UNHCR's Operational Support Division expressed concern over the considerable expected shortfall in government financial contributions to the general program budget. In 1997, the Executive Committee had approved a budget for the general program of us $\$ 452$ million, but only us $\$ 385$ million was available. ${ }^{33}$ The total funds contributed to UNHCR had reached almost us $\$ 970$ million, but the amount received in 1997 had fallen to Us $\$ 805$ million. ${ }^{34}$ At the close of April 1998, UNHCR had acquired us $\$ 100$ million less than on the same date the previous year. ${ }^{35}$

As fiscal problems intensified in the 1990s, the High Commissioner and her officials sought out initiatives that could bring significant savings without seriously damaging 
program delivery. Staff positions at headquarters and in the field were reduced. In July 1998, the number of headquarters posts stood at 731 , down from 815 a year earlier. In the field, positions fell from 4423 in July 1997, to 4038 a year later. ${ }^{36}$ Even with zealous efforts to limit expenditures for all sectors of UNHCR program operations, the proposed budget for the fiscal year 2000 still stood at nearly US $\$ 950$ million. The 2000 budget was first reduced to us $\$ 870$ million but had to be reduced further to us $\$ 824$ million, demonstrating the inability to raise adequate revenues to meet the still acute program needs so clearly identified by UNHCR personnel.

As this new century opens, financial anxiety persists and is reflected in a plethora of decisions that have affected how UNHCR accomplishes its mandate. Before identifying some of them, this paper will briefly discuss the effect that the High Commissioner who directed the Office in the past decade has had on agency operations.

Sadako Agota became High Commissioner in January 1991, after her appointment by the UN Secretary General was confirmed by the GA. During the autumn 1998 session of the GA, she was reappointed for a two-year term, at her request, and fulfilled her mandate at the end of the year 2000. Her years of service have provided much-needed continuity in leadership and direction, following the events in 1989 and 1990, which resulted in the resignations of her two immediate predecessors. Throughout her years as High Commissioner, Mrs. Ogata strove to make UNHCR more administratively efficient, managerially streamlined, and fiscally responsible and accountable. According to one senior official, her style or approach was to push particular proposals or schemes initially on a trial basis so that she could gauge the response of the major donor governments. If she met no significant resistance, she would persist with her plans, but if opposition arose and intensified, rather than entering a protracted struggle, she would make a strategic retreat. ${ }^{37}$

Prior to the appointment of the present un secretary general, Kofi Annan, some observers speculated that Sadako Ogata was under some consideration for this highest post. One source has speculated that, being aware of this possibility, she worked more diligently than ever to reform the operations of UNHCR as a sort of illustration of what she might be in a position to do if she were given the opportunity to address the internal problems of the un system itself. During her decade as High Commissioner, Mrs. Ogata recognized the fiscal and political importance of the major donor governments, especially that of the United States, and did all in her power to meet their preferences in policy and program choices. What then has been the impact of the financial problems and Mrs. Ogata's approach upon the structural, administrative. and organizational operations of UNHCR?

Major donor governments have routinely criticized many UN agencies for their unprofessional management, rampant use of ad hoc administrative practices, and even financial waste. UNHCR has not been exempted from this censure. As financial shortfalls have become more acute for UNHCR, the High Commissioner and her officials, ever sensitive to the humanitarian nature of its mandate and the deepening concerns expressed by governments about their administrative inefficiencies, renewed their efforts to streamline operations in virtually all areas of agency operations. In April 1993, Mrs. Ogata established a working group to focus upon internal program management and operational capacity. This group has subsequently been absorbed by UNHCR's Office of the Comptroller and Management Services but continues to monitor the operations of the agency, constantly on the lookout for inefficiencies and waste. On another front, to save time for Secretariat officials to undertake other tasks, and to free up government representatives from redundant meetings, UNHCR's Standing Committees on International Protection and Administration and Finance were merged into one general standing committee, which now meets three to four times a year and operates as an advisory body between the annual sessions of the Executive Committee..$^{38}$ This new system began functioning in 1996.

At the same time that the one standing committee was formed, the Executive Committee took steps, at the suggestion of the High Commissioner, to strengthen UNHCR's internal comprehensive audit processes. The primary objective was to make management and administrative systems more accountable, transparent, and responsive. These and other efforts for openness and efficiency were to some degree triggered by the un's own Board of Auditors and Advisory Committee on Administrative and Budgetary Questions, which together had indicated that there had been little progress in rectifying several recurrent administrative issues. ${ }^{39}$

The Un's Board of Auditors had also expressed concern over the lack of coordination and controls between UNHCR and its "implementing partners"- a term that describes the scores of non-governmental organizations with which UNHCR has negotiated contractual arrangements to care for and maintain the millions of persons defined to be within the agency's mandate. Anxious to avoid fiscal inefficiencies, the auditors and UNHCR's Executive Committee 
have urged that the activities of contracting partners be audited as well..$^{0}$

During the last three or four years, numerous reports from UNHCR recount the intensifying work to reduce expenses without losing sight of the agency's objectives. UNHCR's own Inspection and Evaluation Service has adopted practices to strengthen oversight in an attempt to pacify the un's auditors and its own Executive Committee. ${ }^{41}$ As an illustration of cost-cutting efforts, UNHCR has re-examined the contractual relationships it had with suppliers of a wide range of goods, to ensure the best possible prices for materials used to assist refugees.

In 1995, UNHCR embarked upon its most extensive initiative to overhaul management and administrative practices and procedures. This ambitious exercise was intended to streamline management, reduce staff positions at headquarters and in the field, introduce powerful information systems, and above all, cut costs. In-house committees and task forces, watched closely by member government representatives, formulated and evaluated numerous schemes to meet the goals of Project Delphi.

Operating on a parallel track, and at the urging of UN auditors and the Executive Committee, UNHCR has used memoranda of understanding to formalize and place on a more business-like footing its relations with UN agencies contracted to assist refugees.

Simultaneously, work also continued between UNHCR and its non-governmental implementing partners to regularize and formalize their cooperative operations. At the same time, uncertainty mounted among UNHCR officials about whether the non-governmental organizations, in fact, could do all that was being asked of them. By the midnineties, these agencies were operating as much as 70 per cent of the UNHCR's field projects. ${ }^{42}$

As international voluntary agencies became a vital component of UNHCR service delivery, having already acquired observer status at annual meetings of the Executive Committee in many instances, they began to ask for more visibility, and possibly even influence, in UNHCR governance. Succinctly put, these agencies sought the opportunity to submit written presentations, and to intervene orally in Executive Committee deliberations, at least occasionally. ${ }^{43}$ Moreover, these UNHCR partners strove to extend their observer status to the three or four meetings held annually by the Standing Committee. While recognizing that the role of non-un bodies was most significant in helping to fulfill the mandate of UNHCR, government representatives on the Executive Committee preferred to keep governance issues in their hands, for the most part. Nevertheless, observer status for voluntary organizations at Standing Committee meetings has been attained.

It is clear that the challenges facing the agency have been enormous, and the search for adequate financial resources and political support for programs has been a persistent goal.

Concern for the physical safety and security of humanitarian personnel employed by UNHCR and other UN and non-governmental agencies has mounted recently. Officials in the field have been held hostage by bandits and terrorist groups, and in a few deplorable instances, personnel have lost their lives, as in Guinea, East Timor, and Chechnya. This rise in violence has profoundly troubled the senior managers at UNHCR as well as the member governments that sit on the Executive Committee. Whenever possible, field personnel are pulled out of regions known to be particularly dangerous. But if refugees and other persons in need are to be assisted, the international humanitarian organizations must continue to take chances in order to fulfill their humanitarian mandates. The problem continues and is not easily resolved.

\section{Conclusion}

One should not be left entirely with an impression of despair and pessimism. Without doubt, UNHCR has had, and continues to have, financial, administrative, and political impediments to conquer. Moreover, the forces and factors that cause refugee movements are still all too apparent. UNHCR and many humanitarian voluntary organizations are being confronted by a seemingly endless series of forced population movements, whether in the Balkans, subSaharan Africa, or Asia. Political instability, which can cause refugee outflows, persists in many parts of the world and can generate refugee flows surprisingly quickly, given the appropriate catalysts. Bleak as this picture may be, UNHCR, its mandate, and its objectives continue to have broad support from the vast majority of governments today, despite imperfections. Moreover, the agency stands as a useful illustration of how the concept of multilateralism can be operationalized.

The multilateral character of the efforts to meaningfully address the global refugee phenomenon are a half-century old now and are firmly in place. No government today questions the need for collective action where refugees need assistance and protection. The establishment of UNHCR fifty years ago, together with its expanding mandate over time, has its basis in the premises of functionalist multilateralism. ${ }^{44}$ The approach has been applied to the refugee phenomenon because it requires cooperation from virtually all governments, if durable solutions are to be achieved. 
As a multilateral vehicle, UNHCR constitutes the centrepiece of an international "regime" or the formal intergovernmental apparatus intended to formulate and accomplish humanitarian programs necessitated by widespread violence and turmoil.

This recognition on the part of governments that UNHCR fulfills a necessary function does not, of course, alleviate the anxiety on several fronts that continues to be experienced by these same governments, as well as by the High Commissioner and other humanitarian voluntary organizations.

Despite all its problems, UNHCR operations continue to expand, to address the chronic and the newer challenges posed by the global refugee phenomenon. Like complex bureaucratic organizations everywhere, UNHCR in its second half-century will continue to undergo managerial and administrative modifications in an effort to more adequately fulfill its mandate. The degree to which it meets the objectives set for it by governments or in-house planners will depend upon available finances, the political will of member governments, and the scope of the world's refugee situation.

\section{Notes}

1. For elaboration on the origins of UNHCR and the global refugee situation in the postwar era, see Gerald Dirks, Canada's Refugee Policy: Indifference or Opportunism? (Kingston and Montreal: McGill-Queen's University Press, 1977), 176-85, and Jacques Vernant, The Refugee in the Postwar World (New York: Random House, 1953).

2. The Convention defined a refugee as "any person who, owing to well founded fear of being persecuted for reasons of race, religion, nationality, membership in a particular social group or political opinion, is outside the country of his nationality and is unable or, owing to such fear, is unwilling to avail himself of the protection of that country..."

3. For a discussion of UNHCR's formative period, see Vernant, The Refugee in the Postwar World, and G. Loescher, Beyond Charity: International Cooperation and the Global Refugee Crisis (New York: Oxford University Press, 1993).

4. A. Cunliffe, "The Refugee Crises: A Study of the Office of the United Nations High Commission for Refugees," Political Studies 48 (1995), 280.

5. The number of refugees eligible for UNHCR protection rose in increments following the forcible expulsion of Ugandan Asians by President Amin in 1972; the violent military coup in Chile in 1973; the Soviet invasion of Afghanistan in 1979; political and social turmoil in Iran during the early 1980s; and civil wars in Angola and Mozambique in Africa, and in El Salvador, Nicaragua, and Guatemala in the Western Hemisphere in that same decade.

6. UNHCR budgets rose constantly. In U.S. dollars, its budget was \$2.3 million in 1960; \$2.5 million in 1965; \$5.2 million in 1970; $\$ 8.1$ million in 1975; \$195.3 million in 1980; $\$ 322.9$ million in
1985; and \$544.2 million in 1990. Department of Public Information, Yearbooks of the United Nations for appropriate years (New York: Department of Public Information).

7. Executive Committee of the High Commissioner's Program (вснср) Forty-third Session, "Note on International Protection," August 25, 1992, para. 10.

8. Ibid., para. 11.

9. Ibid., para. 14 .

10. Ibid., para. 15 .

11. вснср, Forty-fourth Session, "Note on International Protection," August 31, 1993, para. 39.

12. Ibid., para. 45 .

13. ЕСНСР, Forty-sixth Session, "Note on International Protection," September 1, 1995, para. 25.

14. Interview with an official of UNHCR, Toronto, Ontario, December 10, 1998.

15. ECHCP, Forty-sixth Session, "Note on International Protection," September 1, 1995, para. 23.

16. Cunliffe, "The Refugee Crises," 280.

17. ЕснСР, Forty-seventh Session, "Note on International Protection," July 25, 1996, para. 1.

18. ЕСНСР, Forty-ninth Session, October 12, 1998, Report of the 49th Session of the Executive Committee of the High Commissioner's Program.

19. ЕСНCP, Fiftieth Session, "Strengthening Partnerships to Ensure Protection," September 14, 1999. para. 2.

20. вснср, Forty-second Session, "Note on International Protection," September 9, 1991, para. 17.

21. ЕСнсP Forty-first Session, "Note on International Protection," August 27, 1990, para. 1.

22. Ibid

23. ECHCP, Fiftieth Session, "Note on International Protection," July 7, 1999, para. 1.

24. Еснср Forty-fifth Session, "Note on International Protection," September 6, 1994, para. 19.

25. Ibid., para. 19-24.

26. Ibid., para. 48-51.

27. Ibid., para. 32 .

28. Interviews with Canadian officials at the departments of Citizenship and Immigration, Foreign Affairs and International Trade, and the Canadian International Development Agency, January 4, 1999.

29. ЕСНСР, Forty-first Session, "Note on International Protection," August 27, 1990, para. 10.

30. Ibid., para. 18.

31. Department of Public Information, Yearbooks of the United Nations, 1990-96 (New York: Department of Public Information, 1990-6).

32. Cunliffe, "The Refugee Crises," 285-6.

33. "Report of the Tenth Meeting of the Standing Committee to the High Commissioner's Program," February 2-3, 1998.

34. Ibid.

35. "Report of the Eleventh Meeting of the Standing Committee to the High Commissioner's Program," April 28-9, 1998.

36. ЕСНCP, Forty-ninth Session, "Overview of UnHCR Activities, 1997-99," September 28, 1998. 
37. Interview with an official of UNHCR, Toronto, Ontario, December 10, 1998.

38. ЕСНС, "Report of the Extraordinary Meeting of the Executive Committee to the High Commissioner's Program," June 25, 1995.

39. еснст, Forty-sixth Session, "Report of the Standing Committee on Administration and Finance," October 12, 1995.

40. ЕснСР, Forty-sixth Session, "Report of the Executive Committee of the High Commissioner's Program," October 17-20, 1995.

41. ЕСНС, Forty-seventh Session, "Report of the 3rd Meeting of the Standing Committee," June 1, 1996.

42. ECHCP Forty-eighth Session, "Overview of UNHCR Activities, 1996-98,"

43. ЕснСР, Forty-eighth Session, "Report of the 8th Meeting of the Standing Committee," May 30, 1997.

44. J. Caporaso, "International Relations Theory and Multilateralism: The Search for Foundations," International Organization 46, no. 3 (summer 1992): 599-632.

Gerald Dirks is a professor in the Department of Political Science at Brock University, St. Catharines, Ontario. He has taught, researched, and written widely on Canadian immigration and refugee policy, Canadian foreign policy, and the many issues associated with intensifying global migration. 